ISSN: 1813-162X (Print); $2312-7589$ (Online)
available online at: http://www.tj-es.com

\title{
Metallic Oxides for Innovative Refrigerant Thermo-Physical Properties: Mathematical Models
}

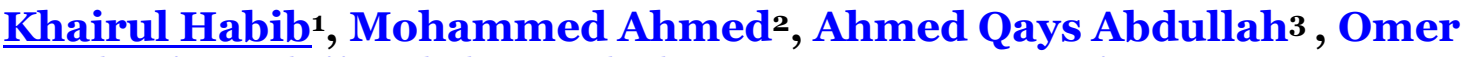 \\ A. Alawi4, Balaji Bakthavatchalam', Omar A. Hussein ${ }^{*} 3$ \\ 1 CEng MIMechE, Mechanical Engineering Department, Universiti Teknologi PETRONAS, 32610 Seri Iskandar, Perak \\ Darul Ridzuan, Malaysia. \\ 2 Department of Mechanical Engineering, College of Engineering, Tikrit University, Tikrit, Iraq. \\ 3 Department of Mechanical Engineering, College of Engineering-Alsharkat, Tikrit University, Tikrit, Iraq. \\ 4 Department of Thermofluids, School of Mechanical Engineering, Universiti Teknologi Malaysia,81310 UTM Skudai, \\ Johor Bahru 81310, Malaysia
}

\section{Keywords:}

Nano-refrigerant; Tube Evaporator;

Refrigeration System; Thermo-physical Properties

\section{A R T I C L E I N F O}

\begin{tabular}{ll}
\hline Article history: & \\
Received & 03 Aug. 2021 \\
Accepted & 01 Nov. 2021 \\
Available online & 15 Nov. 2021
\end{tabular}

(C)2021 COLLEGE OF ENGINEERING, TIKRIT UNIVERSITY. THIS IS AN OPEN ACCESS ARTICLE UNDER THE CC BY LICENSE http://creativecommons.org/licenses/by/4.0/

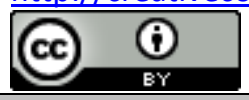

Citation: Habib K, Ahmed M, Abdullah $\mathrm{AQ}$, Alawi OA , Bakthavatchalam B Hussein OA. Metallic Oxides for Innovative Refrigerant Thermo-Physical Properties: Mathematical Models. Tikrit Journal of Engineering Sciences 2022; 29(1): 1- 15. http://doi.org/10.25130/tjes.29.1.1

\section{A B S T R A C T}

Nano-refrigerant is announced to become an excellent refrigerant, which often improves heat transfer efficiency in the cooling systems. Different materials can be applied to be suspended in traditional coolants in the same way as nanoparticles. In this comprehensive research, mathematical modeling was used to investigate the effect of suspended nanoparticles $\left(\mathrm{Al}_{2} \mathrm{O}_{3}, \mathrm{CuO}\right.$, $\mathrm{SiO}_{2}$ and $\mathrm{ZnO}$ ) on 1,1,1,2-Tetrafluoroethane, R134a. The thermal conductivity, dynamic viscosity, density and specific heat capacity of the nanorefrigerant in an evaporator pipe were investigated. Compared to conventional refrigerants, the maximum increase in thermal conductivity was achieved by $\mathrm{Al}_{2} \mathrm{O}_{3} / \mathrm{R}-134 \mathrm{a}$ (96.23\%) at a volume concentration of 0.04 . At the same time, all nano-refrigerant types presented the same viscosity enhancement of $(45.89 \%)$ at the same conditions. These types of complex thermophysical properties have enhanced the heat transfer tendencies in the pipe. Finally, the nanorefrigerant could be a likely working fluid generally used in the cooling unit to improve hightemperature transfer characteristics and save energy use.

\footnotetext{
${ }^{*}$ Corresponding Author : Omar A. Hussein, Mechanical Eng. Dept., College of Eng.-Alsharkat, Tikrit University.
} 


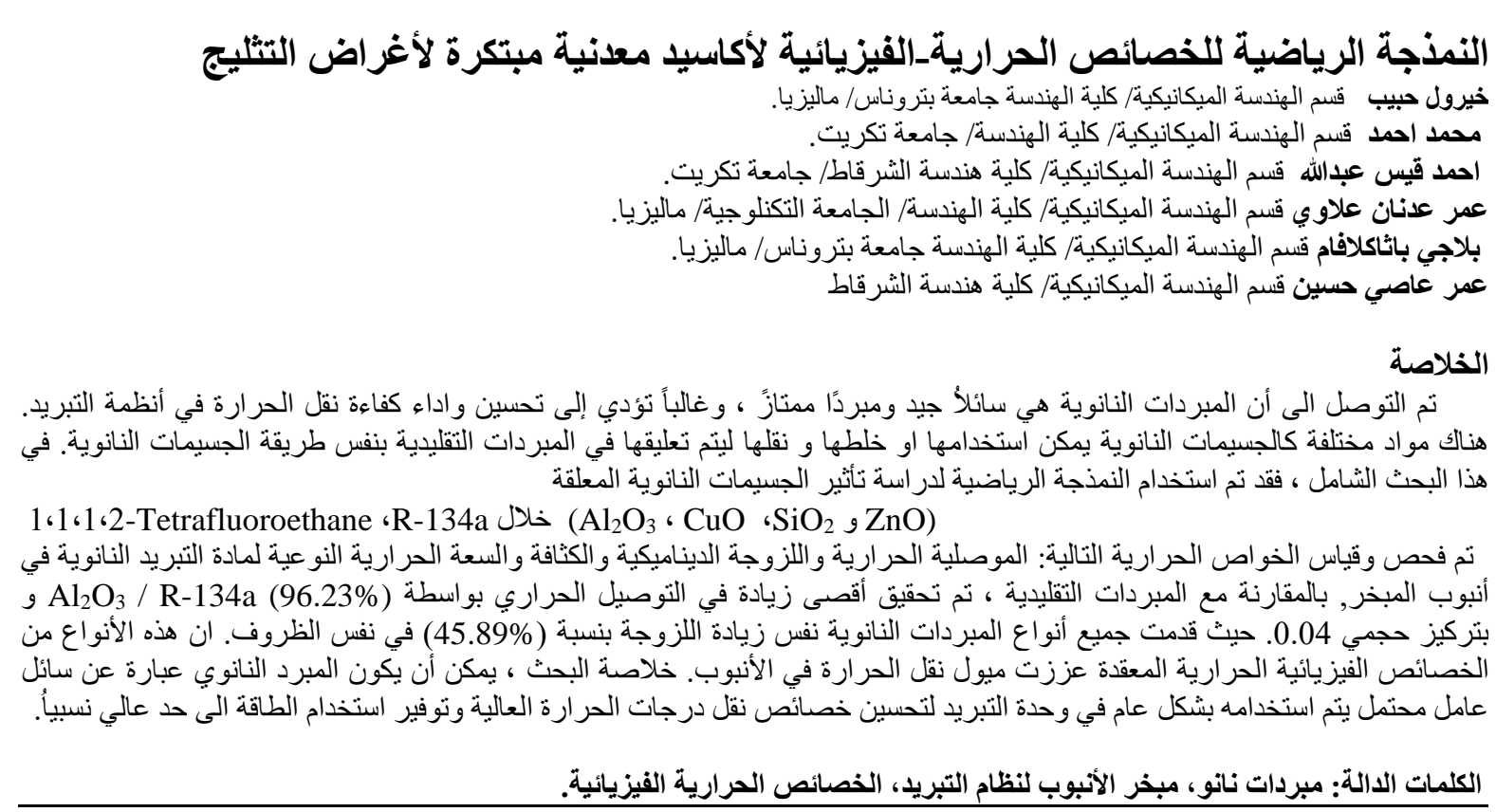

\section{NOMENCLATURE}

$\mathrm{Al}_{2} \mathrm{O}_{3} \quad$ Aluminum oxide

$C_{p} \quad$ Specific Heat, $\mathrm{J} /(\mathrm{kg} \mathrm{K})$

$\mathrm{CuO}$ Copper oxide

$d_{p} \quad$ Diameter of nanoparticles, $\mathrm{nm}$

$g \quad$ Gravitational acceleration, $\mathrm{m} / \mathrm{s}^{2}$

$h_{\text {air }} \quad$ Air heat transfer coefficient, $\mathrm{W} /\left(\mathrm{m}^{2} \mathrm{~K}\right)$

$k \quad$ Thermal conductivity, $\mathrm{W} /(\mathrm{m} \mathrm{K})$

$k_{\text {Copper }} \quad$ Thermal conductivity of copper, $\mathrm{W} /(\mathrm{m} \mathrm{K})$

$L \quad$ Tube length, $\mathrm{mm}$

\section{Greek symbols}

$\alpha \quad$ Thermal diffusivity, $\mathrm{m}^{2} \mathrm{~s}^{-1}$

$\beta \quad$ Coefficient of thermal expansion, $1 / \mathrm{K}$

$\mu \quad$ Dynamic viscosity, Pa s

\section{Subscripts}

$\begin{array}{ll}f & \text { Fluid } \\ m & \text { Refrigerant } \\ n_{f} & \text { Nanorefrigerant }\end{array}$

\section{INTRODUCTION}

Replacement of conventional refrigerants such as R134a and R12, in system refrigerants is essential and currently ongoing. This effort is to reduce: (i) the impact of conventional refrigerants on climate change (especially Ozone depletion and/or high global warming) [1], (ii) high energy consumption and exergy destruction [2], thereby enabling compact design of refrigerator systems [3], and (iii) rate of refrigerant leakage to the environment [4]. Design simplicity and economic advantage of
$R e_{m} \quad$ Nanorefrigerant Reynolds number

$R_{\text {in }} \quad$ Inner radius, $\mathrm{mm}$

$R_{o} \quad$ Outer radius, $\mathrm{mm}$

$\mathrm{SiO}_{2} \quad$ Silicon oxide

$T_{i} \quad$ Temperature of the inner cylinder, $\mathrm{K}$

$T_{o} \quad$ Temperature of the outer cylinder, $\mathrm{K}$

$V \quad$ Refrigerant velocity, $\mathrm{m} / \mathrm{s}$

$\mathrm{ZnO}$ Zinc oxide $\begin{array}{ll}n_{p} & \text { Nanoparticles } \\ s & \text { Solid }\end{array}$

domestic refrigerators are increasing their applications in households, and commercial buildings. According to International Institute of Refrigeration (IIR), more than $17 \%$ of energy consumption globally are from refrigeration and air conditioning systems [5].

Nanotechnology can be described as a science and technology area for modifying and using of particles within the atomic and molecular structure. A particle is recognized as a small element that usually provides a unique 
transportation factor and its specific characteristics [6]. Despite the need for established physical properties from mass materials, the material characteristics vary with their unique nano-size specifications [7]. Depending on their diameter, these types of particles could be classified into three categories, including coarse-particles (10,000$2500) \mathrm{nm}$, fine-particles (2500-100) $\mathrm{nm}$, and ultrafine-particles or perhaps nano-particles (1-100) $\mathrm{nm}$. In heat transfer approaches, the application of ultrafine particles becomes necessary, as the use of the particles with a larger size contributes to many complications, such as fouling, sedimentation and then a reduction in pressure [8].

The use of conventional heat transfer fluids, including water, engine oil, and ethylene glycol, often leads to limitations in the efficiency and performance of thermal devices of a given size. The increase in heat transfer could be allowed by maintaining suspended solid particles as a chemical component in these conventional fluids [6]. Thermal conductivity is undoubtedly an essential thermophysical feature to improve the performance of such suspension systems $[4,5]$. To improve the thermal conductivity of standard fluids, nanoparticles in a base fluid, in which the thermal conductivity of the particles is incredibly higher than the base fluid, are suspended. Nanoparticles and the base fluid are called nano-fluids, which are a sophisticated form of heat transfer fluids [11].

A new promising heat transfer fluid known as nanofluid has contributed to many applications today, such as electronics, nuclear reactors, biomedical, motor vehicle, and industrial cooling. Recently, nano-refrigerants have been introduced as significant effects of nanoparticles on heat transfer efficiency and energy consumption elimination [12]. Past nanofluid experiments have presented that small nano particular concentrations have a promising potential to enhance base-fluid thermo-physical properties [13]. Subsequently, there was a tremendous investigation into the suspension of nanoparticles in the conventional refrigerant. Research has shown that nanoparticles suspended in Malaysian residential refrigerators can reduce energy consumption by approximately 10,863 MWh by 2030 [14].

Many studies to analyze the thermal conductivity of the nanofluids have already been carried out. On the other hand, there are specific pieces of literature on the thermal conductivity of nano-refrigerants [15]. Once again, researchers agreed that the concentration of nanoparticles and various nanoparticles improved the thermal conductivity of the nano-refrigerant [16]. Long-term stability of the dispersion of nanoparticles affects the thermal conductivity of the nano-refrigerant, as a better dispersion tendency reveals the superior thermal conductivity of the nano-refrigerant [17]. Also, it demonstrated significant impacts of $\mathrm{Al}_{2} \mathrm{O}_{3}$ nano-particle volume percentage on the thermal and pressure drop of R141b refrigerants using constant temperature, mass flow, and pressure by using mathematical modeling suggestions [12]. It is recommended that the suspension system of $\mathrm{Al}_{2} \mathrm{O}_{3}$ nanoparticles in $\mathrm{R}-134 \mathrm{a}$ refrigerant reduces power consumption by about $10.32 \%$ by just $0.2 \%$ of the suspension of nanoparticles [18]. Under the standard reports, $\mathrm{TiO}_{2}$-R6ooa concentrations of 0.1 and $0.5 \mathrm{~g} \mathrm{~L}^{-1}$ decreased by $5.94 \%$ and energy performance by $9.60 \%$ in the residential refrigerator respectively [19]. The cooling unit with mineral oil and $\mathrm{Al}_{2} \mathrm{O}_{3}$ nanoparticles electricity consumption by about $25 \%$ compared to conventional oil [20]. Subsequently, the nano-lubricant $\mathrm{Al}_{2} \mathrm{O}_{3} / \mathrm{R} 600$ a reduced the electric power consumption of the compressor by approximately $11.5 \%$ increased by $19.6 \%$ due to the nano lubricant compared to the standard POE (polyol-ester) oil and the coefficient of performance of the refrigeration unit [21]. There are many reasons for the thermal conductivity of the nano-refrigerant, for example, the fraction of particle volume, the classes of nanoparticles, refrigerants, particle sizes and particle patterns [22]. The thermal conductivity of the $\mathrm{Al}_{2} \mathrm{O}_{3}$ nanoparticles could be improved by only increasing the volume of nanoparticles suspended in the R-134a refrigerant [23]. The thermal conductivity of $\mathrm{Al}_{2} \mathrm{O}_{3} / \mathrm{R} 141 \mathrm{~b}$ nano-refrigerant improved with 0.5-2 nanoparticle volume concentrations and temperature range of $5-20^{\circ} \mathrm{C}$, while the viscosity of the nano-refrigerant increased with increase the concentration of nanoparticles but reduced with temperature [15].

The viscosity of nanoparticles based on R134a refrigerant could also be theoretically improved due to the nanoparticles concentration of 0.01 to 0.05 [18]. The study usually showed that the concentration of the $\mathrm{TiO}_{2}$ nanoparticles in a horizontally smooth tube led to the drop in pumping power, pressure and heat transfer coefficient of nanorefrigerant [24]. The coefficient of heat transfer in the cooling unit affected the heat transfer rate. The increase in the heat transfer coefficient due to the concentration of $\mathrm{Al}_{2} \mathrm{O}_{3}$ nanoparticles was acquired for single-phase laminar flow in the micro channel, while external deposition, clustering of nanoparticles 
and cluster occur in the two-phase system [25]. The objective of this research is to improve the thermal conductivity, dynamic viscosity, density and specific heat capacity of the nano-refrigerants in an evaporator tube using mathematical models.

Table 1

Thermo-physical properties of pure refrigerant and various types of nano-fluids at $300 \mathrm{~K}$ [18].

\begin{tabular}{|c|c|c|c|c|c|}
\hline Thermophysical Properties & R134a & $\mathrm{Al}_{2} \mathrm{O}_{3}$ & $\mathrm{CuO}$ & $\mathrm{ZnO}$ & $\mathrm{SiO}_{2}$ \\
\hline Density, $\rho\left(\mathrm{kg} / \mathrm{m}^{3}\right)$ & 1199.7 & 3970 & 6500 & 5600 & 2200 \\
\hline Dynamic viscosity, $\mu$ ( $m P a s$ ) & 0.191 & - & - & - & - \\
\hline Thermal Conductivity, $k$ (W/m K) & $\begin{array}{c}8.03 \times 10^{-} \\
2\end{array}$ & 36 & 17.65 & 13 & 1.4 \\
\hline Specific heat, $\mathrm{Cp}(\mathrm{J} / \mathrm{kg} \mathrm{K})$ & 1432 & 765 & 535 & 495.2 & 745 \\
\hline
\end{tabular}

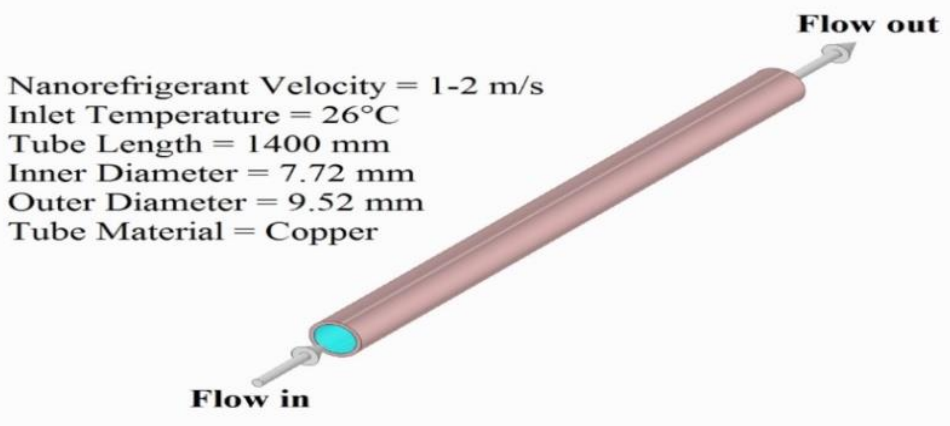

Fig. 1. A nano-refrigerant evaporator tube [27].

Table 2

Values of specification for nano-refrigerant properties [27].

\begin{tabular}{ll}
\hline Constant parameter & Value \\
\hline Refrigerant velocity, $V$ & $1-2 \mathrm{~m} / \mathrm{s}$ \\
Diameter of nanoparticles, $d_{\mathrm{p}}$ & $20-80 \mathrm{~nm}$ \\
\hline Thermal Conductivity of copper, $k_{\text {copper }}$ & $401 \mathrm{~W} /(\mathrm{m} \mathrm{K})$ \\
Heat transfer coefficient for air, $h_{\text {air }}$ & $50 \mathrm{~W} /\left(\mathrm{m}^{2} \mathrm{~K}\right)$ \\
$\mathrm{T}_{\text {inlet }}, T_{i}$ & $26^{\circ} \mathrm{C}$ \\
Temperature outlet, $T_{o}$ & $10^{\circ} \mathrm{C}$ \\
\hline
\end{tabular}

2. THERMO-PHYSICAL PROPERTIES AND MATHEMATICAL MODELS

\subsection{Nano-refrigerant and Tube Design}

The thermo-physical properties of nanorefrigerants were studied in this research by investigating nano-particles $\left(\mathrm{Al}_{2} \mathrm{O}_{3}, \mathrm{CuO}, \mathrm{SiO}_{2}\right.$, and $\mathrm{ZnO}$ ) and the regular refrigerant $\mathrm{R}-134 \mathrm{a}$. Table 1 shows physical characteristics of nanoadditives and pure cooling [26]. A copper smooth flat evaporator pipe was created with a CAD software program with internal diameter $(D i)$, and length $(L),(7.72 \mathrm{~mm})$ and $(1400$ $\mathrm{mm}$ ), respectively. Fig. 1 shows the evaporator copper tube. In determining the properties of the nano-refrigerant, various factors of the initial state in the evaporation approach were fully developed flow. Table 2 displays the constant parameters used for this research study.

\subsection{Mathematical Models of Nano- refrigerant}

Nano-refrigerant thermal conductivity is estimated using data from Table 3 and the mathematical modeling of [28] as follows: 
$\frac{k_{n f}}{k_{m}}=c R e_{m}^{0.175} \varphi_{p}^{0.05}\left[\frac{k_{p}}{k_{m}}\right]^{0.2324}$

where $k_{n f}$ is the thermal conductivity of nanofluid, $k_{m}$ is the thermal conductivity of refrigerant, $k_{p}$ is the thermal conductivity of nanoparticles, $c$ is constant in the equation (1.298), $\varphi_{p}$ is the particle volume fraction, $V_{m}$ is the velocity of the refrigerant in the rang(1-2 $\left.\mathrm{m} \mathrm{s}^{-1}\right), \rho_{p}$ is the density of nanoparticles, $d_{p}$ is the diameter of nanoparticles refrigerant in the rang (20-80nm), and $T_{\text {in }}$ is the temperature inlet. Table 3 displays the constant parameters used for this research study.

The Reynolds number of nano-refrigerant is estimated by applying equation (2) as follows:

$R e_{m}=\left(\frac{1}{V_{m}}\right)\left[\frac{18 k_{p} T_{i n}}{\pi \rho_{p} d_{p}}\right]^{0.5}$

By using Brownian nano-particular motion, the effective viscosity can be obtained through subsequent empirical correlation [29]:

$\frac{\mu_{\text {eff }}}{\mu_{f}}=\frac{1}{1-34.87\left(\frac{d_{p}}{d_{f}}\right)^{-0.3} \varphi^{1.03}}$
Equivalent diameter of base-fluid molecule [29]:

$d_{f}=\frac{6 M}{N \pi \rho b_{f}}$

where $M$ is the molecular weight of the base fluid, $\mathrm{N}$ is the Avogadro number, $f$ refers to nanofluid, $\mathrm{b}_{f}$ refers to base fluid and $\mathrm{p}$ refers to nanoparticle.

The density of the nano-fluid $\rho_{n f}$ can be evaluated [30]:

$\rho_{n f}=(1-\varphi) \rho_{f}+\varphi \rho_{n p}$

The mass densities of the base-fluid and the solid nano-particles were $\rho_{f}$ and $\rho_{n p}$, respectively. The effect of the specific heat capacity $(\rho C p)_{n f}$ could be determined at a constant pressure of the nano-fluid [30]:

$(\rho C p)_{n f}=(1-\varphi)(\rho C p)_{f}+\varphi(\rho C p)_{n p}$

Table 3
Values of specification for nano-refrigerant properties.

\begin{tabular}{lc}
\hline Constant parameter & Value \\
\hline Refrigerant velocity, $V$ & $1-2 \mathrm{~m} / \mathrm{s}$ \\
Diameter of-nanoparticles, $d_{\mathrm{p}}$ & $20-80 \mathrm{~nm}$ \\
$\mathrm{~T}_{\text {inlet }}, T_{i}$ & $26^{\circ} \mathrm{C}$ \\
Temperature outlet, $T_{o}$ & $10^{\circ} \mathrm{C}$ \\
\hline
\end{tabular}

\section{RESULTS AND DISCUSSION}

\subsection{Thermal Conductivity of Nano- refrigerants}

Fig. 2 and Table 4 showed the association with nano-refrigerant thermal conductivity, R-134a refrigerant and nano-particle volume fraction. Nanorefrigerant thermal conductivity $k_{n f}$ was directly proportional to the nanoparticle volume fraction. The thermal conductivity of pure coolant, 0.0803 W(m K) improved by adding 0.01 volume fraction of nanoparticles and an increase in $95.96 \%, 94.7 \%, 89.16 \%$ and $94.23 \%$, respectively.

The substantial improvement was due to the consideration of the surface layer in mathematical modeling. It designed the corresponding particles without overlying between particles [31]. Applying a nanoparticle volume fraction of about 0.04 improved the thermal conductivity of the nano-refrigerant by far extra than $100 \%$, as the standard refrigerant R-134a offered superior thermal conductivity to various base-fluids, such as water, oil and ethylene glycol.

In particular, the thermal conductivity of the nano-refrigerant will probably be improved as a result of the addition of nanoparticles to the nano-refrigerant [32]. The viscosity of the nano-refrigerant should as well be measured, as it could affect the overall enactment of the cooling unit.

Results show the thermal conductivity of the metal oxides nanofluids increases linearly 
with nanoparticle concentration. By applying the current proposed model of, $\mathrm{Al}_{2} \mathrm{O}_{3}, \mathrm{CuO}$, and $\mathrm{ZnO}$ have greater thermal conductivity ratio compared to Maxwell model [33]. On the other hand, $\mathrm{SiO}_{2}$ shows less thermal conductivity ratio due to its lower thermal conductivity among the four metal oxides nanofluid used in this investigation. Overall, it can be concluded that the thermal conductivity of nanofluid increases with nanoparticle volume fractions.

Based on the results in Table 4, it is outstandingly evident that nano-refrigerant provide a significant thermal conductivity enhancement compared to those of other works

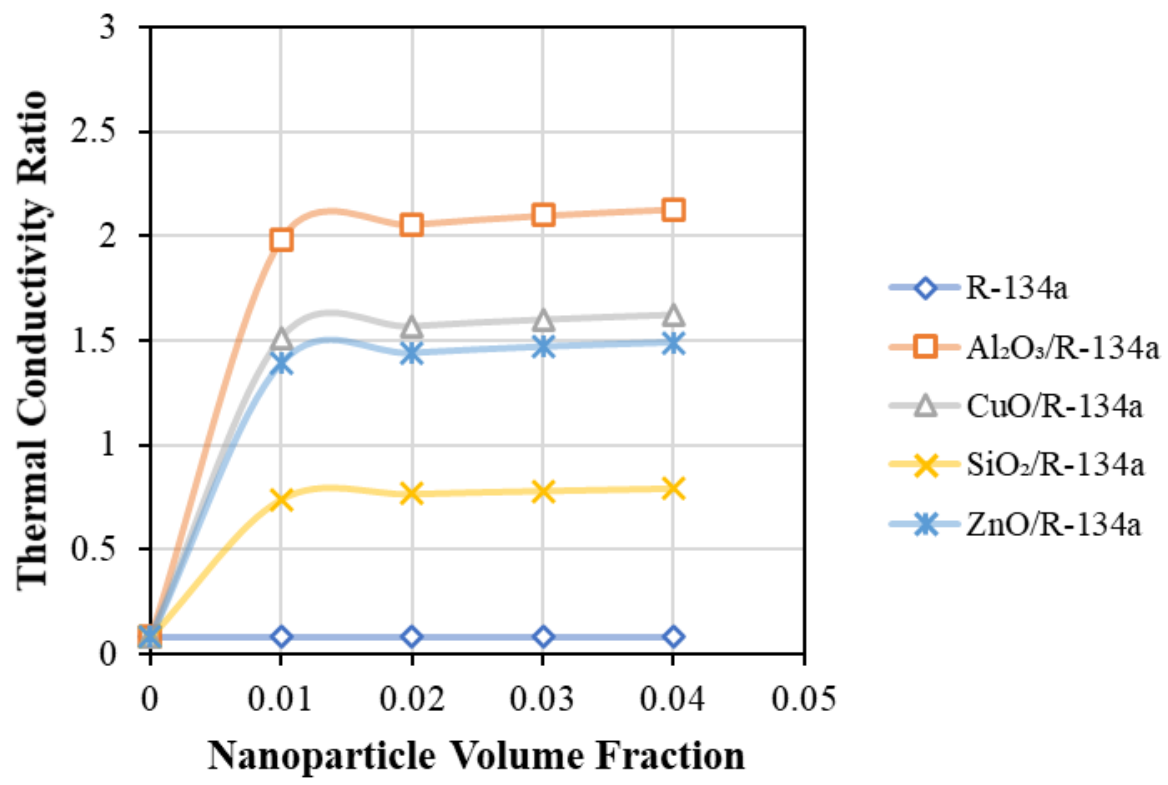

Fig. 2. Variation of thermal conductivity as a function of $\varphi$ with different types of nanoparticles at $V=$ $1 \mathrm{~m} / \mathrm{s}$ and $\mathrm{d}_{\mathrm{p}}=20 \mathrm{~nm}$

\section{Table 4}

Summary of thermal conductivity investigations of nano-refrigerants.

\begin{tabular}{|c|c|c|c|c|}
\hline Reference & NPs & Refrigerant & $\begin{array}{l}\text { Operational } \\
\text { conditions }\end{array}$ & Findings \\
\hline [31] & $\begin{array}{l}\mathrm{Cu}, \mathrm{Al}, \mathrm{Ni} \\
\mathrm{CuO} \\
\mathrm{Al}_{2} \mathrm{O}_{3}\end{array}$ & $\overline{\mathrm{R}-113}$ & $\mathrm{~T}=303 \mathrm{~K}$ & $\begin{array}{l}\text { Increases sharply up to } 20 \% \\
\text { with increase in } \varphi(0.01) .\end{array}$ \\
\hline [34] & $\mathrm{Al}_{2} \mathrm{O}_{3}$ & $\mathrm{R}-141 \mathrm{~b}$ & $\begin{array}{l}\left(\mathrm{T}=5-30^{\circ} \mathrm{C}\right) \\
(\varphi=0.1-0.4)\end{array}$ & $\begin{array}{l}\text { It increases by } 1.626 \text { times on } \\
(0.2) \text { concentration and } 20^{\circ} \mathrm{C} \text {. }\end{array}$ \\
\hline [35] & $\mathrm{Al}_{2} \mathrm{O}_{3}$ & $\mathrm{R}-134 \mathrm{a}$ & $\begin{array}{l}\mathrm{T}=283-308 \mathrm{~K}, \mathrm{u}=5 \\
\mathrm{~m} / \mathrm{s},(\varphi=0.01-0.05), \\
\text { mass flux }=100 \mathrm{~kg} \mathrm{~m}^{-2}\end{array}$ & $\begin{array}{l}\text { Maximum improvement of } \\
28.58 \% \text {. }\end{array}$ \\
\hline [22] & $\mathrm{CuO}$ & $\mathrm{R}-134 \mathrm{a}$ & $\begin{array}{l}(\varphi=0.01-0.05), d_{p}=20 \\
n m,(T=300-325 K)\end{array}$ & $\begin{array}{l}\text { Maximum improvement of } \\
43 \% \text {. }\end{array}$ \\
\hline [18] & $\mathrm{Al}_{2} \mathrm{O}_{3}$ & $\mathrm{R}-134 \mathrm{a}$ & $\begin{array}{l}(\varphi=0.01-0.05), d_{p}=20 \\
n m,(T=300-325 K)\end{array}$ & $\begin{array}{l}\text { Rises with an increase in } \\
\text { particle concentration and } \\
\text { temperature and with decrease } \\
\text { in additives size. }\end{array}$ \\
\hline [36] & SWCNT & $\mathrm{R}-134 \mathrm{a}$ & $\begin{array}{l}\varphi=(0.01-0.05), d_{p}=20 \\
n m, T=300-325 K\end{array}$ & $\begin{array}{l}\text { Increases with increase in } \\
\text { particle concentration and } \\
\text { temperature. }\end{array}$ \\
\hline $\begin{array}{l}\text { Current } \\
\text { study }\end{array}$ & $\begin{array}{l}\mathrm{Al}_{2} \mathrm{O}_{3} \\
\mathrm{CuO}, \mathrm{SiO}_{2} \\
\mathrm{ZnO}\end{array}$ & $\mathrm{R}-134 \mathrm{a}$ & $\begin{array}{l}\varphi=(0.01-0.04), d_{p}= \\
2 O-80 \mathrm{~nm}, T=225^{-} 325 \\
K, \mathrm{u}=1-2 \mathrm{~m} \mathrm{~s}^{-1}\end{array}$ & $\begin{array}{l}\text { Increases with increase in } \\
\text { particle volume and } \\
\text { temperature. }\end{array}$ \\
\hline
\end{tabular}


when they have higher concentrations of nanoparticles. These results show that using a low concentration of nano-refrigerant can achieve good thermal conductivity enhancement for medium-temperature applications including cooling and heat exchanger systems.

Figs. 3-5 showed thermal conductivity of $\left(\mathrm{Al}_{2} \mathrm{O}_{3} / \mathrm{R}-134 \mathrm{a}\right)$ with different nanoparticle diameters, nano-refrigerant temperatures, and velocity as a function of the nanoparticle volume fraction. Nano-refrigerant thermal conductivity decreases by increasing the diameter of nanoparticles. This was due to smaller particles that convey more collision space. The arbitrary movement of microscopic particles mixed in the base-fluid allows other collisions with bordering structure molecules and minimizes the wall temperature [28]. By increasing the nano-refrigerant temperature, the thermal conductivity was shown in Fig. 4 improved because of equation (2), the number of Reynolds was immediately proportional to the nano-refrigerant temperature. As a result of equation (2), the thermal conductivity of nano-refrigerants was reduced by increasing the fluid velocity, as shown in Fig. 5.

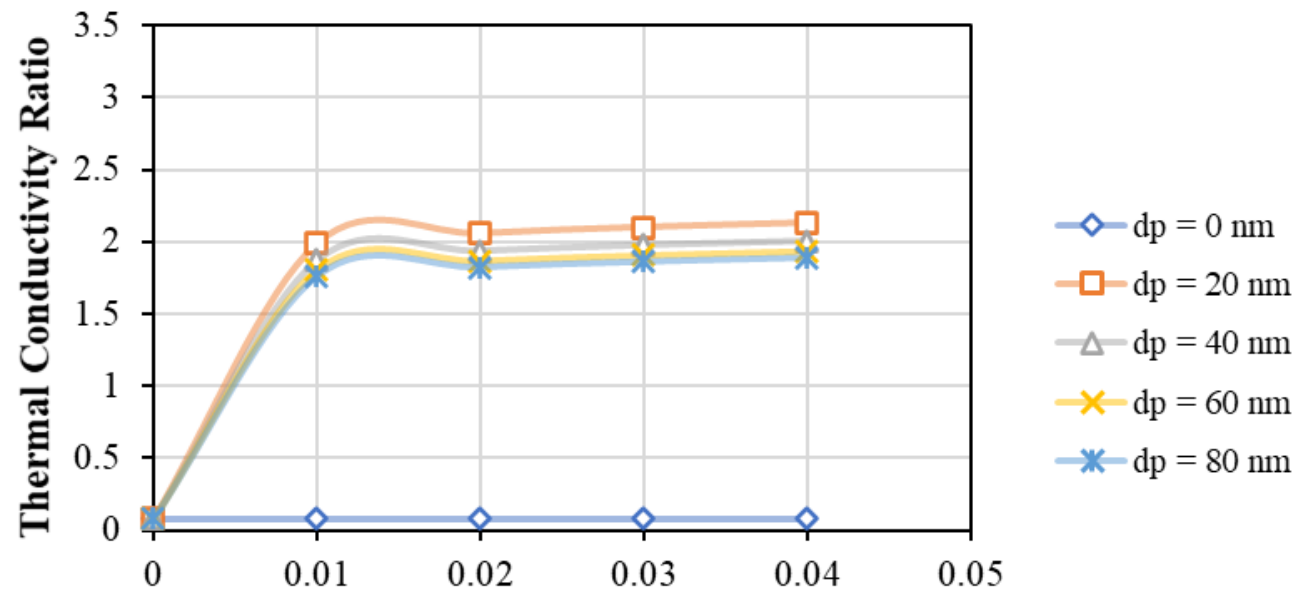

Nanoparticle Volume Fraction

Fig. 3. Variation of thermal conductivity as a function of nano-particle volume fraction with different diameters of nanoparticles at $\mathrm{V}=1 \mathrm{~m} / \mathrm{s}$.

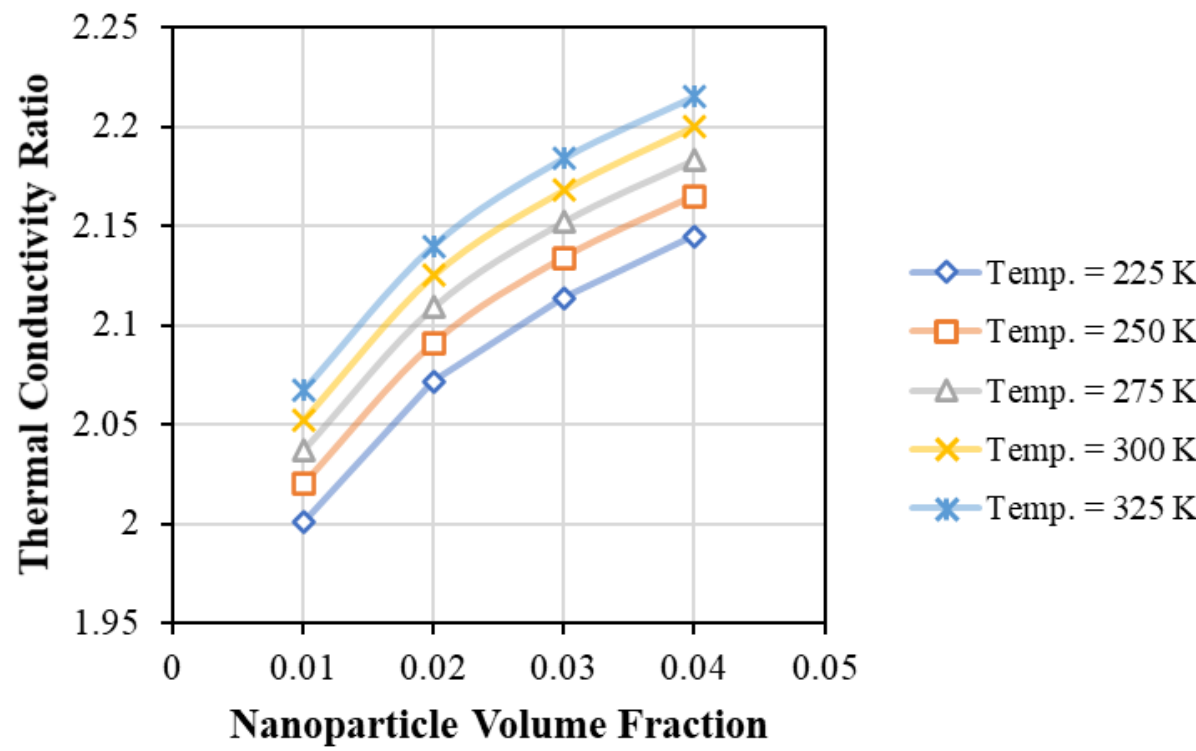

Fig. 4. Variation of thermal conductivity as a function of nano-particle volume fraction with different nano-refrigerant temperatures at $\mathrm{V}=1 \mathrm{~m} / \mathrm{s}$ and $\mathrm{d}_{\mathrm{p}}=20 \mathrm{~nm}$. 


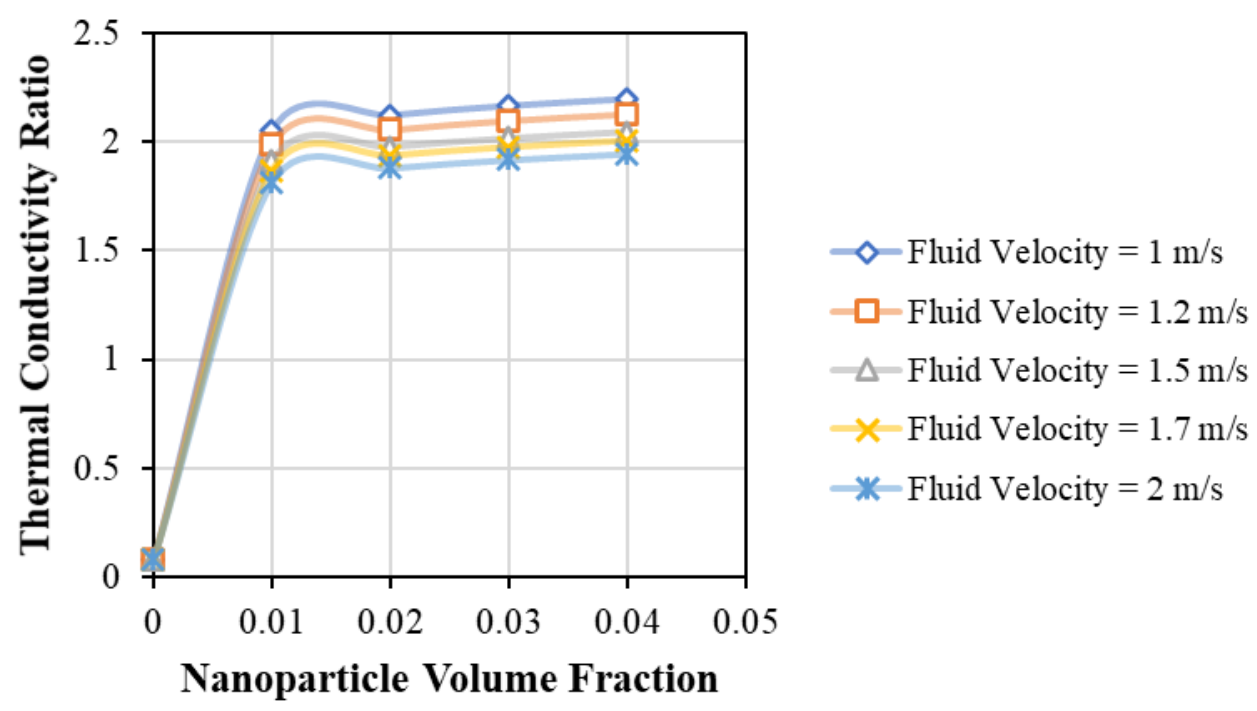

Fig. 5. Variation of thermal conductivity as a function of nano-particle volume fraction with different nano-refrigerant velocities at Temp. $=325 \mathrm{~K}$ and $\mathrm{d}_{\mathrm{p}}=20 \mathrm{~nm}$.

\subsection{Dynamic Viscosity of Nano- refrigerants}

Increases in nano-refrigerant viscosity in line for the nanoparticle remark presented in Fig. 6 . The viscosity was instantly proportionate to the volume of nanoparticles. R-134a viscosity at $300 \mathrm{~K}$ was $0.191 \mathrm{mPa}$ s. After the nanoparticles were suspended in the refrigerant at 0.01 nano-particle volume, the viscosity improved to $0.214 \mathrm{mPa} \mathrm{s}$, about $10.75 \%$ improvement, as shown in Fig. 9. A more significant increase in the nanorefrigerant's viscosity was achieved by suspending an additional 0.01 of the nanoparticle volumes. The pendent nanoparticles have improved the surface area through the R-134a refrigerant and the additives. The Brownian motion arbitrarily drifted the nano-particles into the nanorefrigerant, which improved the tube convection process. As metal oxides in size of nanoparticles, it allows even additional motions caused by the gap between particles and collisions [27]. Table 5 summarizes the results of dynamic viscosity measurement from different researchers on nanorefrigerants.

More recent works that compared the Current study are listed in Table 5. Based on Table 5, improve viscosity offers significant evidence that nano-refrigerant, had higher concentrations of additives or nanoparticle in comparison to other samples. It is highlighted here that medium-temperature applications can achieve suitable viscosity by using lowvolume fraction.

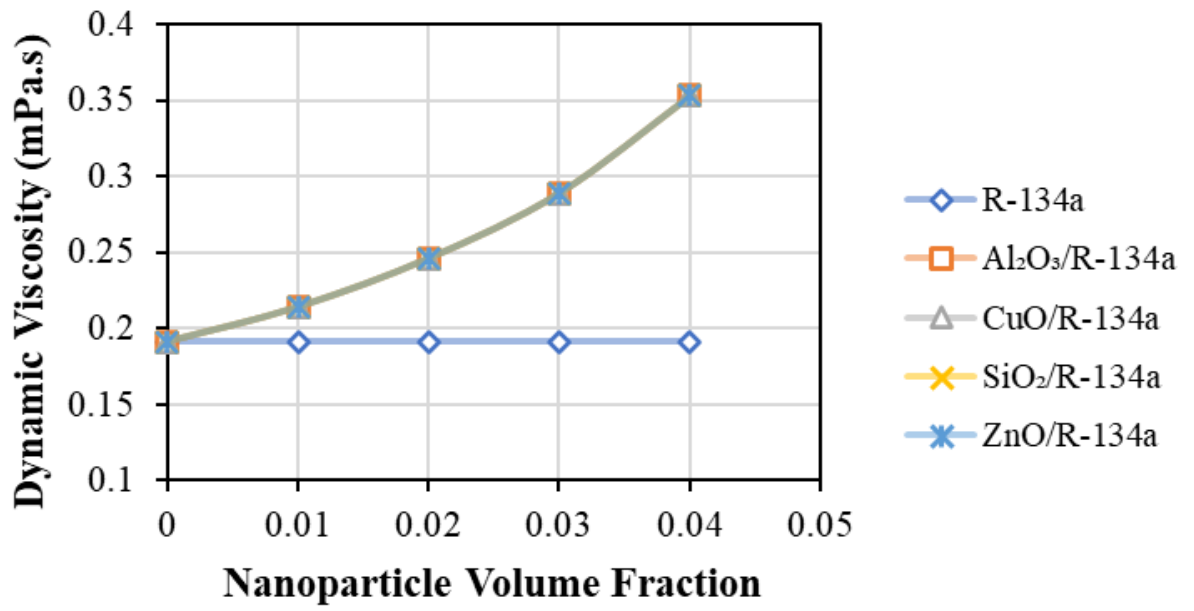

Fig. 6. Variation of viscosity as a function of nano-particle volume fraction at $V=1 \mathrm{~m} / \mathrm{s}$ and $d_{p}=20$ $\mathrm{nm}$. 
Table 5

Summary of investigations on dynamic viscosity of nanorefrigerants.

\begin{tabular}{|c|c|c|c|c|}
\hline Reference & NPs & Refrigerant & Operational conditions & Findings \\
\hline [37] & $\mathrm{TiO}_{2}$ & $\mathrm{R}-123$ & $\begin{array}{l}\left(\text { Temp. }=5-20^{\circ} \mathrm{C}\right), \varphi=0.5- \\
2.0\end{array}$ & $\begin{array}{l}\text { Viscosity increased with the } \\
\text { rise in } \varphi \text { and reduction with } \\
\text { an increase in T. }\end{array}$ \\
\hline [15] & $\mathrm{Al}_{2} \mathrm{O}_{3}$ & R-141b & $\begin{array}{l}\left(\text { Temp. }=5-30^{\circ} \mathrm{C}\right) \\
\varphi=0.1-0.4\end{array}$ & $\begin{array}{l}\text { Viscosity growing by } 179 \\
\text { times at } 5^{\circ} \text { Cand } 0.2\end{array}$ \\
\hline [35] & $\mathrm{Al}_{2} \mathrm{O}_{3}$ & $\mathrm{R}-134 \mathrm{a}$ & $\begin{array}{l}(\text { Temp. }=283-308 \mathrm{~K}), \mathrm{u}=5 \\
\mathrm{~m} \mathrm{~s}^{-1},(\varphi=0.01-0.05), \text { mass } \\
\text { flux }=100 \mathrm{~kg} \mathrm{~m}^{-2}\end{array}$ & $\begin{array}{l}\text { Increased by } 13.68 \% \text { for } \\
\text { same temperature. }\end{array}$ \\
\hline [22] & $\mathrm{CuO}$ & $\mathrm{R}-134 \mathrm{a}$ & $\begin{array}{l}\varphi_{\mathrm{np}}=(0.01-0.05), \mathrm{d}_{\mathrm{p}}=20 \mathrm{~nm}, \\
\mathrm{~T}=300-325 \mathrm{~K}\end{array}$ & $\begin{array}{l}\text { Viscosity raise with the } \\
\text { increase in } \varphi \text { and reduce in } \\
\text { T. }\end{array}$ \\
\hline [18] & $\mathrm{Al}_{2} \mathrm{O}_{3}$ & $\mathrm{R}-134 \mathrm{a}$ & $\begin{array}{l}\varphi_{\mathrm{np}}=(0.01-0.05), \mathrm{d}_{\mathrm{p}}=20 \\
\mathrm{~nm}, \mathrm{~T}=300-325 \mathrm{~K}\end{array}$ & $\begin{array}{l}\text { Viscosity increases with the } \\
\text { increase in } \varphi \text {. }\end{array}$ \\
\hline [36] & SWCNT & $\mathrm{R}-134 \mathrm{a}$ & $\begin{array}{l}\varphi_{\text {np }}=(0.01-0.05), d_{p}=20 \\
n m, T=300-325 K\end{array}$ & $\begin{array}{l}\text { Viscosity increases with the } \\
\text { increase in } \varphi \text { and decrease in } \\
\text { T. }\end{array}$ \\
\hline $\begin{array}{l}\text { Current } \\
\text { study }\end{array}$ & $\begin{array}{l}\mathrm{Al}_{2} \mathrm{O}_{3}, \mathrm{CuO} \\
\mathrm{SiO}_{2}, \mathrm{ZnO}\end{array}$ & $(\mathrm{R}-134 \mathrm{a})$ & $\begin{array}{l}\varphi_{\mathrm{np}}=(0.01-0.04), \mathrm{d}_{\mathrm{p}}=20-80 \\
\mathrm{~nm}, \mathrm{~T}=225-325 \mathrm{~K}, \mathrm{u}=1-2 \mathrm{~m} \\
\mathrm{~s}^{-1}\end{array}$ & $\begin{array}{l}\text { Viscosity increased with the } \\
\text { rise in } \varphi \text { and reduction with } \\
\text { increase in } T \text {. }\end{array}$ \\
\hline
\end{tabular}

\subsection{Density of Nano-refrigerants}

Fig. 7 presents the variation of the prepared nano-refrigerant density with respect to the change in volume concentration. From the graph, it is clear that the density of the proposed fluids decreased dramatically except R-134a which doesn't show any significant change. The density was directly proportionate to the volume fraction of nanoparticles. R-134a density in $300 \mathrm{~K}$ is $1199.7 \mathrm{~kg} \mathrm{~m}^{-3}$. After the nano additives in the refrigerant were suspended at 0.01 nanoparticle volume fraction, the density of $\mathrm{Al}_{2} \mathrm{O}_{3}, \mathrm{CuO}, \mathrm{SiO}_{2}$ and $\mathrm{ZnO}$ obtained by approximately 2.26, 4.23,
0.83 and $3.54 \%$ respectively, as shown in Fig. 9. Table 6 summarizes the results of density measurement from different researchers on nano-refrigerants.

The results show the different behaviour of the density of the nanofluids, while the data confirm that the temperature affects the density of the nanofluids. The density of the nanofluids exceeds that of its basefluid due to the increase in the temperature. If the nanoparticles volume concentration increases from 0.01 to 0.04 , its density decreases as shown in Fig. 7.

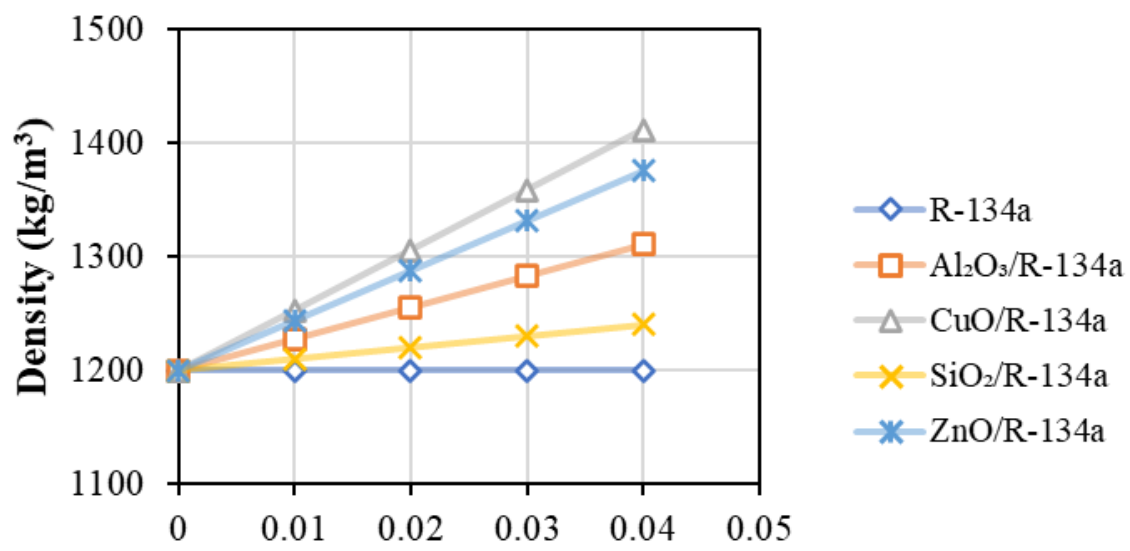

Nanoparticle Volume Fraction 


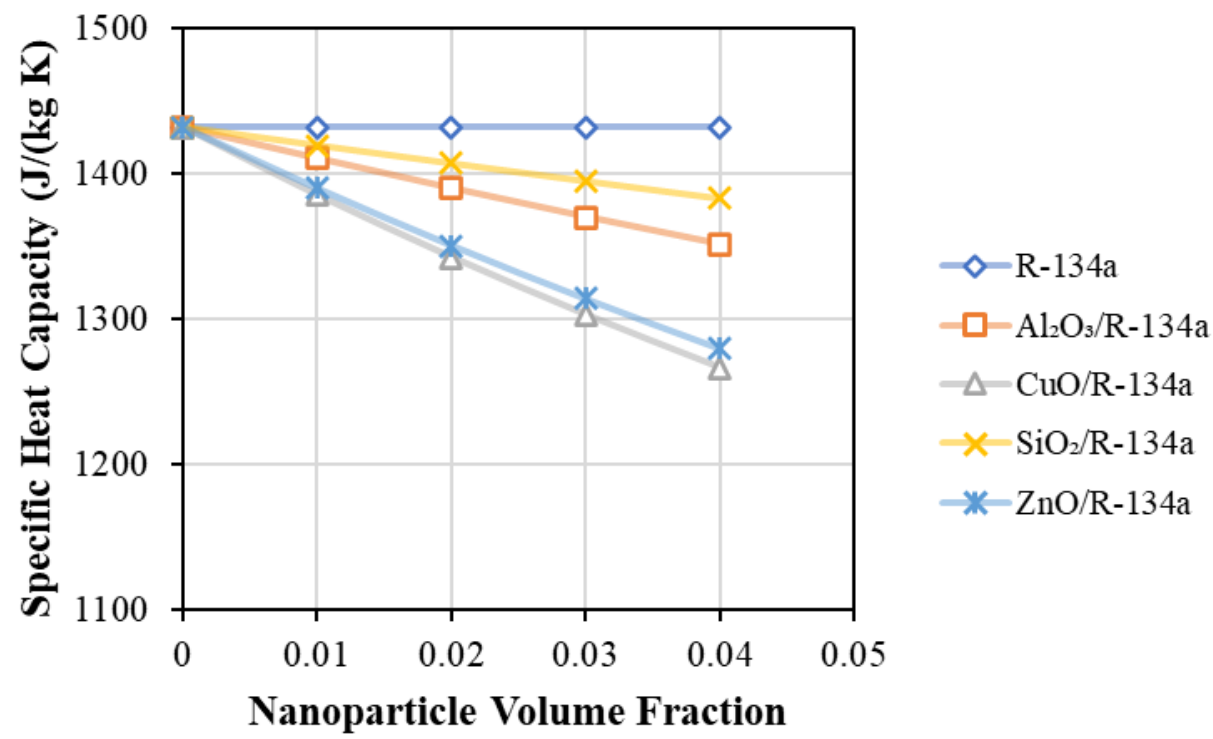

Fig. 8. Variation of specific Heat as a function of $\varphi$ at $V=1 \mathrm{~m} / \mathrm{s}$ and $d_{p}=20 \mathrm{~nm}$.
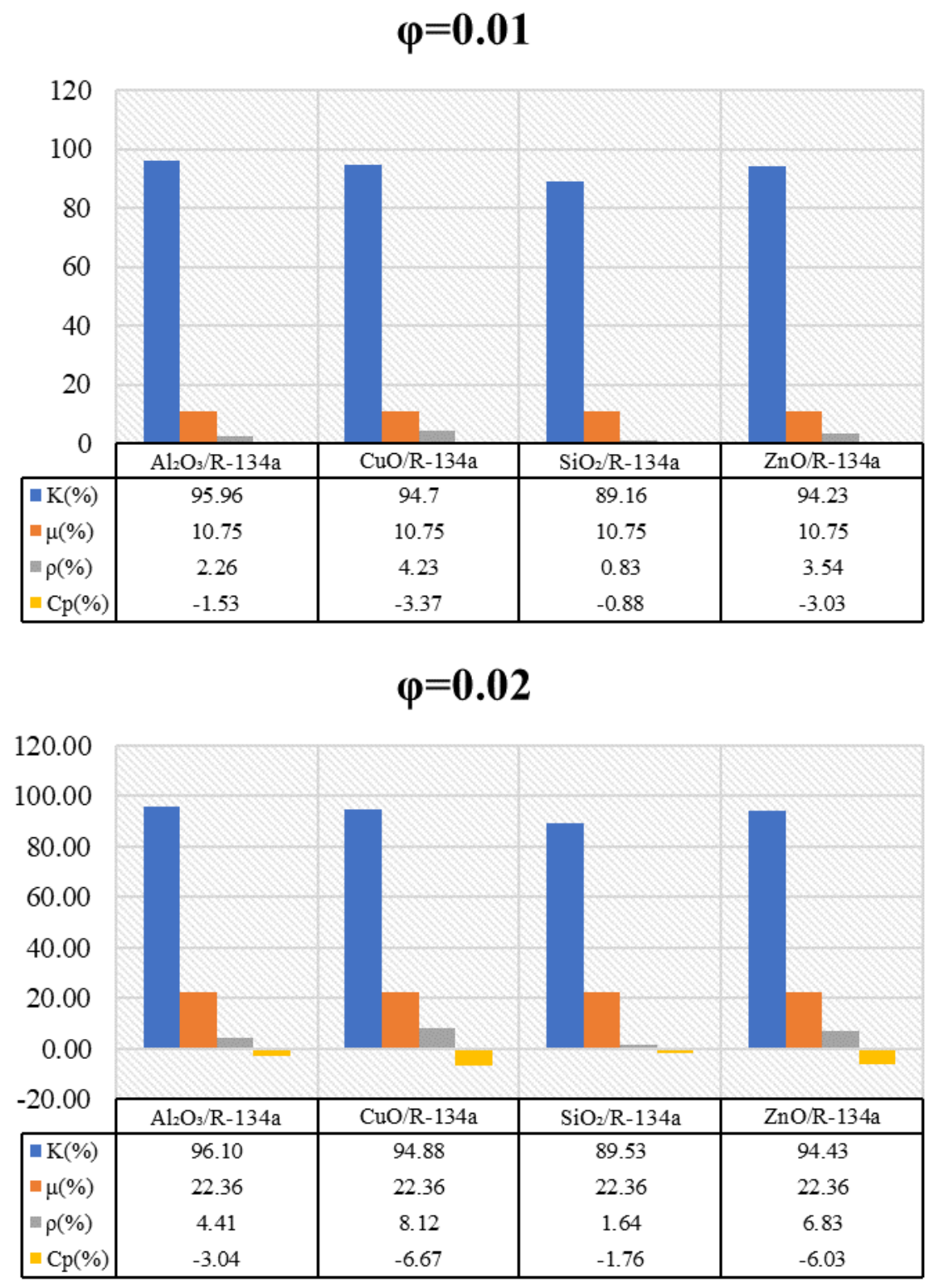


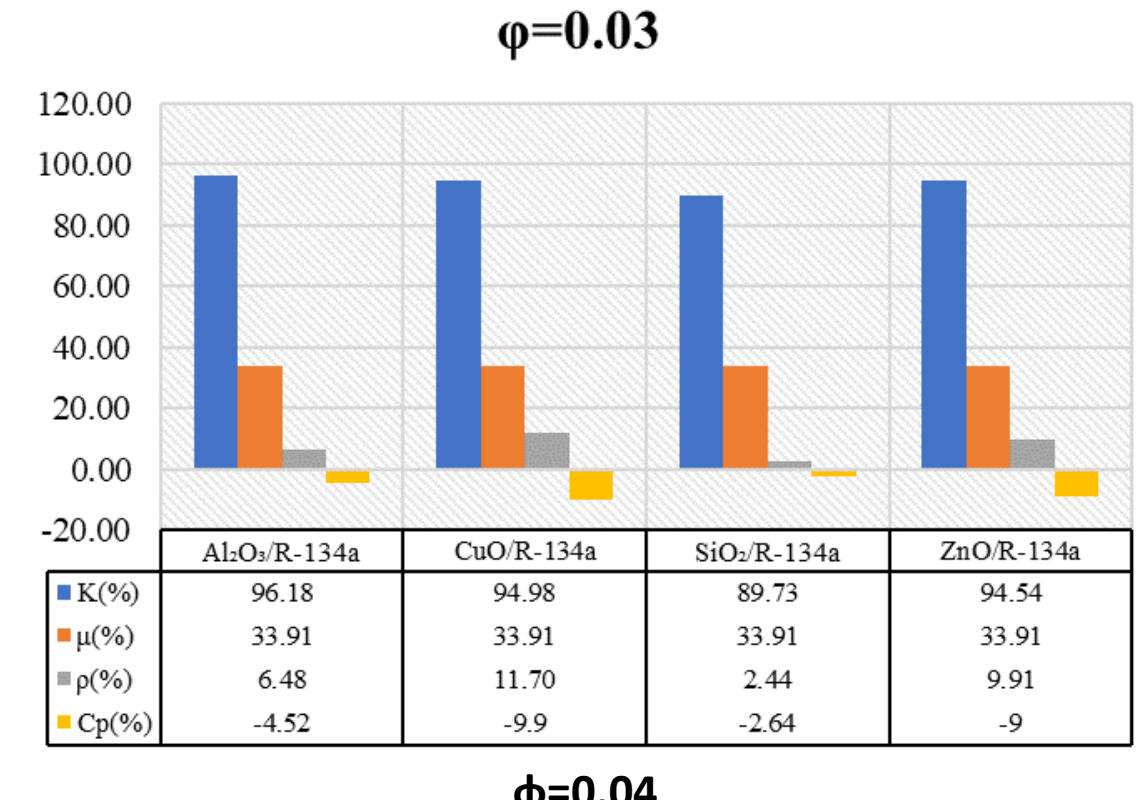

$\phi=0.04$

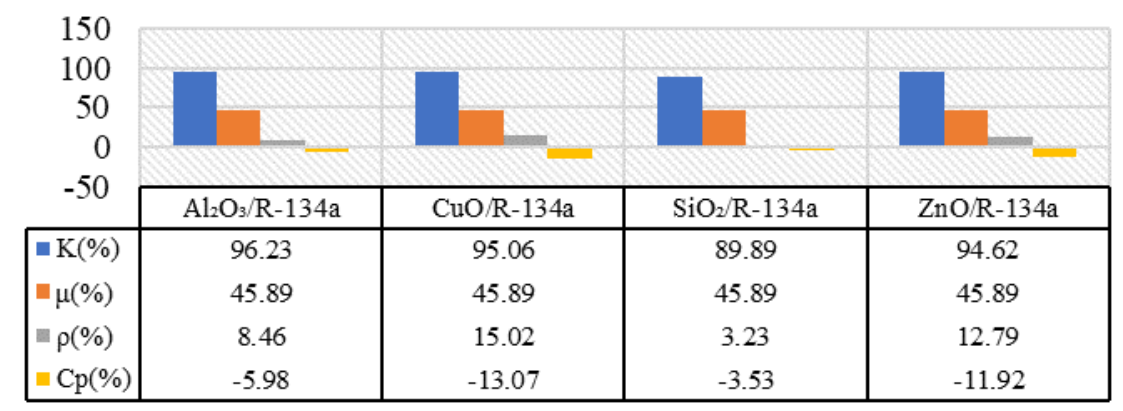

Fig. 9. Nano-refrigerant thermo-physical properties enhancement at different nano-particles volume fractions.

Table 7

Summary of investigations on the specific heat capacity of nano-refrigerants.

\begin{tabular}{|c|c|c|c|c|}
\hline Reference & NPs & Refrigerant & Operational conditions & Findings \\
\hline$[35]$ & $\mathrm{Al}_{2} \mathrm{O}_{3}$ & $\mathrm{R}-134 \mathrm{a}$ & $\begin{array}{l}\text { Temp. }=283-308 \mathrm{~K}, \varphi_{\mathrm{np}}= \\
0.05\end{array}$ & $\begin{array}{l}\text { Heat capacity } \\
\text { increases with } \\
\text { temperature. }\end{array}$ \\
\hline [36] & SWCNT & $\mathrm{R}-134 \mathrm{a}$ & $\begin{array}{l}\varphi_{\mathrm{np}}=0.01-0.05, \mathrm{~d}_{\mathrm{p}}=20 \\
\mathrm{~nm}, T=300-325 \mathrm{~K}\end{array}$ & $\begin{array}{l}\text { Specific heat rises } \\
\text { with increase in } \mathrm{T} \\
\text { and } \varphi \text {. }\end{array}$ \\
\hline $\begin{array}{l}\text { Current } \\
\text { study }\end{array}$ & $\begin{array}{l}\mathrm{Al}_{2} \mathrm{O}_{3}, \mathrm{CuO} \\
\mathrm{SiO}_{2}, \mathrm{ZnO}\end{array}$ & $\mathrm{R}-134 \mathrm{a}$ & $\begin{array}{l}\varphi_{\mathrm{np}}=0.01-0.04, \mathrm{~d}_{\mathrm{p}}=20- \\
80 \mathrm{~nm}, \mathrm{Temp} .=225-325 \\
\mathrm{~K}, u=1-2 \mathrm{~m} / \mathrm{s}^{-1}\end{array}$ & $\begin{array}{l}\text { Decreases with } \\
\text { increase in } \varphi .\end{array}$ \\
\hline
\end{tabular}

\section{CONCLUSION}

The thermal conductivity and the rheological behaviour of nano refrigerants based on metallic oxides were discussed. Mathematical models using different types of nanoparticles $\left(\mathrm{Al}_{2} \mathrm{O}_{3}, \mathrm{CuO}, \mathrm{SiO}_{2}\right.$, and $\left.\mathrm{ZnO}\right)$ were used to estimate the thermo-physical properties of nano-refrigerants using a cooling unit evaporator tube. The thermal conductivity of the $\mathrm{Al}_{2} \mathrm{O}_{3} / \mathrm{R}-134$ a coolant was $0.0803 \mathrm{~W} / \mathrm{m}$. K at $300 \mathrm{~K}$ temperature and 0.01 of the nanoparticles volume fractions Suspending. The fraction of refrigerant nano-particles improved thermal conductivity by around 95.96\% $\left(\mathrm{Al}_{2} \mathrm{O}_{3} / \mathrm{R}-134 \mathrm{a}\right)$. More than 0.01 of the nanoparticles volume fractions had thermal conductivity ranging from 95.96 to 96.23 within 0.01 to 0.04 of the nanoparticles volume fractions. The viscosity of the nanorefrigerant also showed a remarkable increase of $10.75 \%$ compared to the standard refrigerant, with only 0.01 of the nanoparticles 
volume fractions. Volume fractions of nanoparticles and the temperature of the mixture have significant effects on the thermal conductivity and viscosity of the nanofluids. Results indicate that viscosity increases with the increment of the particle volume fractions. However, it decreases when the temperature increases.

Nano-refrigerant density and specific heat capacity showed significant improvements in nano-particles suspended based on a volume fraction. It is essential to have the nanorefrigerant's excellent thermal properties that can withstand the variation of temperature and pressure, and the nanoparticles would probably not cause the cooling, corrosion or pressure drop in the cooling unit's efficiency.

\section{REFERENCES}

[1] J. M. Calm, "The next generation of refrigerants - Historical review, considerations, and outlook," Int. J. Refrig., vol. 31, no. 7, pp. 1123-1133, 2008.

[2] B. O. Bolaji and Z. Huan, "Ozone depletion and global warming: Case for the use of natural refrigerant - A review," Renew. Sustain. Energy Rev., vol. 18, pp. 49-54, 2013.

[3] F. Ghadiri and M. Rasti, "The effect of selecting proper refrigeration cycle components on optimizing energy consumption of the household refrigerators," Appl. Therm. Eng., vol. 67, no. 1-2, pp. 335-340, 2014.

[4] D. S. Adelekan, O. S. Ohunakin, J. Gill, A. A. Atayero, C. D. Diarra, and E. A. Asuzu, "Experimental performance of a safe charge of LPG refrigerant enhanced with varying concentrations of $\mathrm{TiO} 2$ nanolubricant in a domestic refrigerator," $J$. Therm. Anal. Calorim., vol. 136, no. 6, pp. 2439-2448, 2019.

[5] Z. Zhu, K. Liang, Z. Li, H. Jiang, and Z. Meng, "Thermal-economicenvironmental analysis on household refrigerator using a variable displacement compressor and low-GWP refrigerants," Int. J. Refrig., vol. 123, pp. 189-197, 2021.

[6] A. Celen, A. Çebi, M. Aktas, O. Mahian, A. S. Dalkilic, and S. Wongwises, "A review of nanorefrigerants: flow characteristics and applications," Int. J. Refrig., vol. 44, pp. 125-140, 2014.

[7] A. Bhattad, J. Sarkar, and P. Ghosh, "Improving the performance of refrigeration systems by using nanofluids: A comprehensive review," Renew. Sustain. Energy Rev., 2017.

[8] V. Nair, P. R. Tailor, and A. D. Parekh, "Nanorefrigerants: A comprehensive review on its past, present and future," International Journal of Refrigeration, vol. 67. pp. 290-307, 2016.

[9] O. A. Alawi, N. A. C. Sidik, and H. A. Mohammed, "A comprehensive review of fundamentals, preparation and applications of nanorefrigerants," Int. Commun. Heat Mass Transf., vol. 54, pp. 81-95, 2014.

[10] O. A. Hussein, K. Habib, M. Nasif, R. Saidur, and A. S. Muhsan, "Investigation of stability, dispersion, and thermal conductivity of functionalized multiwalled carbon nanotube based nanofluid," in IOP Conference Series: Materials Science and Engineering, 2020, vol. 863, no. 1.

[11] W. H. Azmi, M. Z. Sharif, T. M. Yusof, R. Mamat, and A. A. M. Redhwan, "Potential of nanorefrigerant and nanolubricant on energy saving in refrigeration system - A review," Renewable and Sustainable Energy Reviews. 2017.

[12] I. M. Mahbubul, R. Saidur, and M. A. Amalina, "Heat transfer and pressure drop characteristics of $\mathrm{Al}_{2} \mathrm{O} 3-\mathrm{R} 141 \mathrm{~b}$ nanorefrigerant in horizontal smooth circular tube," Procedia Eng., vol. 56, pp. 323-329, 2013.

[13] D. S. Kumar and R. Elansezhian, "Experimental study on $\mathrm{Al} 2 \mathrm{O} 3-\mathrm{R} 134 \mathrm{a}$ nano refrigerant in refrigeration system," Int. J. Mod. Eng. Res., vol. 2, no. 5, pp. 3927-3929, 2012.

[14] F. S. Javadi and R. Saidur, "Energetic, economic and environmental impacts of using nanorefrigerant in domestic refrigerators in Malaysia," Energy Convers. Manag., vol. 73, pp. 335-339, 2013.

[15] I. M. Mahbubul, R. Saidur, and M. A. Amalina, "Influence of particle concentration and temperature on thermal conductivity and viscosity of $\mathrm{Al}_{2} \mathrm{O} 3 / \mathrm{R} 141 \mathrm{~b}$ nanorefrigerant," Int. Commun. Heat Mass Transf., vol. 43, pp. 100-104, 2013.

[16] O. A. Alawi, N. A. C. Sidik, and M. Beriache, "Applications of nanorefrigerant and nanolubricants in refrigeration, air-conditioning and heat pump systems: A review," Int. Commun. Heat Mass Transf., vol. 68, pp. 91-97, 2015.

[17] G. Ding, H. Peng, W. Jiang, and Y. Gao, "The migration characteristics of nanoparticles in the pool boiling process of nanorefrigerant and nanorefrigerantoil mixture," Int. J. Refrig., vol. 32, no. 1, pp. 114-123, 2009.

[18] O. A. Alawi and N. A. C. Sidik, "Mathematical correlations on factors affecting the thermal conductivity and 
dynamic viscosity of nanorefrigerants,"

Int. Commun. Heat Mass Transf., vol. 58, pp. 125-131, 2014.

[19] S. Bi, K. Guo, Z. Liu, and J. Wu, "Performance of a domestic refrigerator using TiO2-R6ooa nano-refrigerant as working fluid," in Energy Conversion and Management, 2011, vol. 52, no. 1, pp. 733-737.

[20] N. Subramani and M. J. Prakash, "Experimental studies on a vapour compression system using nanorefrigerants," Int. J. Eng. Sci. Technol., vol. 3, no. 9, pp. 95-102, 2011.

[21] R. R. Kumar, K. Sridhar, and M. Narasimha, "Heat transfer enhancement in domestic refrigerator using $\mathrm{R} 600 a / m i n e r a l$ oil/nano- $\mathrm{Al}_{2} \mathrm{O}_{3}$ as working fluid," Int. J. Comput. Eng. Res., vol. 3, no. 4, pp. 42-50, 2013.

[22] O. A. Alawi and N. A. C. Sidik, "Influence of particle concentration and temperature on the thermophysical properties of $\mathrm{CuO} / \mathrm{R} 134 \mathrm{a}$ nanorefrigerant," Int. Commun. Heat Mass Transf., vol. 58, pp. 79-84, 2014.

[23] A. Kasaeian, S. M. Hosseini, M. Sheikhpour, O. Mahian, W. M. Yan, and S. Wongwises, "Applications of ecofriendly refrigerants and nanorefrigerants: A review," Renewable and Sustainable Energy Reviews. 2018.

[24] O. A. Alawi, N. A. C. Sidik, and A. S. Kherbeet, "Measurements and correlations of frictional pressure drop of TiO2/R123 flow boiling inside a horizontal smooth tube," Int. Commun. Heat Mass Transf., vol. 61, pp. 42-48, 2015.

[25] S. S. Sanukrishna, M. Murukan, and P. M. Jose, "An overview of experimental studies on nanorefrigerants: Recent research, development and applications," Int. J. Refrig., vol. 88, pp. 552-577, 2018.

[26] H. Peng, G. Ding, W. Jiang, H. Hu, and Y. Gao, "Heat transfer characteristics of refrigerant-based nanofluid flow boiling inside a horizontal smooth tube," Int. J. Refrig., vol. 32, no. 6, pp. 1259-1270, 2009.

[27] S. A. Fadhilah, R. S. Marhamah, and A. H. M. Izzat, "Copper Oxide Nanoparticles for Advanced Refrigerant Thermophysical Properties: Mathematical Modeling," $J$. Nanoparticles, vol. 2014, pp. 1-5, 2014.

[28] V. Velagapudi, K. R. Konijeti, and K. S. C. Aduru, "Empirical correlations to predict thermophysical and heat transfer characteristics of nanofluids," Therm. Sci., vol. 12, no. 2, pp. 27-37, 2008.

[29] R. K. Tiwari and M. K. Das, "Heat transfer augmentation in a two-sided lid-driven differentially heated square cavity utilizing nanofluids," Int. J. Heat Mass Transf., vol. 50, no. 9-10, pp. 20022018, 2007.

[30] B. Ghasemi and S. M. Aminossadati, "Brownian motion of nanoparticles in a triangular enclosure with natural convection," Int. J. Therm. Sci., vol. 49, no. 6, pp. 931-940, Jun. 2010.

[31] W. Jiang, G. Ding, H. Peng, Y. Gao, and K. Wang, "Experimental and model research on nanorefrigerant thermal conductivity," HVAC R Res., 2009.

[32] S. S. Sanukrishna, A. S. Vishnu, and M. Jose Prakash, "Nanorefrigerants for energy efficient refrigeration systems," $J$. Mech. Sci. Technol., vol. 31, no. 8, pp. 3993-4001, 2017.

[33] E. V. Timofeeva et al., "Thermal conductivity and particle agglomeration in alumina nanofluids: Experiment and theory," Phys. Rev. E - Stat. Nonlinear, Soft Matter Phys., vol. 76, no. 6, 2007.

[34] I. M. Mahbubul, R. Saidur, and M. A. Amalina, "Thermal conductivity, viscosity and density of R141b refrigerant based nanofluid," in Procedia Engineering, 
2013, vol. 56, pp. 310-315.

[35] I. M. Mahbubul, A. Saadah, R. Saidur, M.

A. Khairul, and A. Kamyar, "Thermal performance analysis of $\mathrm{Al}_{2} \mathrm{O}_{3} / \mathrm{R}-134 \mathrm{a}$ nanorefrigerant," Int. J. Heat Mass Transf., vol. 85, pp. 1034-1040, 2015.

[36] O. A. Alawi and N. A. C. Sidik, "The effect of temperature and particles concentration on the determination of thermo and physical properties of SWCNT-nanorefrigerant," Int. Commun. Heat Mass Transf., vol. 67, pp. 8-13, 2015.

[37] I. M. Mahbubul, R. Saidur, and M. A. Amalina, "Investigation of viscosity of R123-TIO2nanorefrigerant," Int. J. Mech. Mater. Eng., 2012. 